\title{
Organizational Factors and Quality of Production in Malaysia's Manufacturing Companies
}

\author{
Julian Paul Sidin ${ }^{1}$ \\ ${ }^{1}$ School of Business \& Economics, Universiti Malaysia Sabah, Sabah, Malaysia \\ Correspondence: Julian Paul Sidin, School of Business \& Economics, Universiti Malaysia Sabah, Jalan UMS, \\ 88400 Kota Kinabalu, Sabah, Malaysia. E-mail: jpsidin@ums.edu.my
}

Received: February 13, 2014

Accepted: March 13, $2014 \quad$ Online Published: March 21, 2014

doi:10.5539/ijbm.v9n4p1

URL: http://dx.doi.org/10.5539/ijbm.v9n4p1

\begin{abstract}
The purpose of this study is to ascertain whether there is any correlation between organizational factors and quality of production in Malaysia's manufacturing companies. A theoretical model of the relationships among the constructs of organizational factors that consist of organizational resources, rewards and recognition structure, and information system and quality of production are proposed and tested using multi-regression analysis. The results showed positive relationship between organizational factors and quality of production in Malaysia's manufacturing industry, except for one which is related to rewards and recognition structure. The findings of this study will assist managers to make appropriate decisions when adopting the three elements in their respective organizations especially in the manufacturing sector.
\end{abstract}

Keywords: organizational resources, rewards and recognition structure, information system, quality of production, manufacturing

\section{Introduction}

The aim of this study is to give insight into organizational factors that contribute to high-quality results in production of manufacturing companies in Malaysia. In the year 2003, the Vice-President of Federation of Malaysian Manufacturers, Raja Abdul Aziz Raja Musa, stated that Malaysia's manufacturing sector is experiencing a significant gap between the information system and overall resources, therefore causing more delays in the overall processes on manufacturing management. He added that the manufacturing sector in Malaysia has a problem in maintaining its competitiveness, quality and Just-in-Time delivery. Some manufacturers will outsource their production in order to maintain competitiveness. According to the Federation of Malaysian Manufacturers in 2003, most people in the Malaysia's manufacturing sector are yet to master the information and communication technology for the purpose of business and manufacturing as some of these companies are still working with the conventional manufacturing processes.

In order to study the aforementioned issues above, the researcher has to include the basic demographic characteristics of manufacturing companies in Malaysia to corroborate information in this study, which named as organizational factors as the mould of characters of an organization which is very important to shape an organizational readiness for change. The purpose of this study is to elucidate the types of organizational factors associated with quality of production in Malaysia's manufacturing companies.

This study describes the data analysis undertaken to assess the results using statistical approach and reports the results of the factor analysis, reliability for each of the studied constructs and descriptive results of the study. From the results of the analysis, it was found that there were a positive association between organizational factors and quality production, especially organizational resources and information system which stood alongside with previous studies. Perhaps, the most surprising result is there was no statistically significant relationship between rewards and recognition structure and quality of production in Malaysia's manufacturing companies.

\section{Literature Review}

Several researchers have identified relevant factors of organization that significantly influence performance: greater integration, process optimization, and improved access to information (Seddon et al., 2010); skills, culture and organizational climate (Hajihashemi \& Javadi, 2011); resources, partnership, employee participation, 
and level of trust (Naji et al., 2012); strategy and risk taking, structure and reward system (Khakbaz et al., 2011); leadership and managerial support (Mora-Valentin et al., 2004). By analyzing the commonalities among the various descriptions found in an extensive earlier literature review, this study has identified three major factors underlying organization characteristics and management practices that are key conditions essential for the enhancement of organizational performance. These three factors are organizational resources, rewards and recognition structure, and information system.

\subsection{Organizational Resources}

Research on organizational competitive advantages clarifies the importance of organizational resources to the long term sustained competitive advantage of the firm (Ndofor et al., 2011). Most literatures usually define the major resources used by organizations to accomplish goals as human resources, financial resources, physical resources, information resources, and infrastructure (Mithas \& Narayan, 2011; Lu \& Ramamurthy, 2011). However, Barney (1986) has a broader meaning of organizational resources which include all the organization's assets, its capabilities, processes designed and applied by the organization, the organization attributes, knowledge, etc.

One of the most significant developments in the field of organization in recent times is the increasing importance given to organizational resources. Fahy (2000) claims that there is a significant relationship between resources and competitive advantage in terms of superior firm performance, characteristics and types of advantage generating resources, and strategic choice by management. According to Chaplin (1991), organizational resources are valuable to businesses, and it is important to understand about allocation of these resources. Being able to appropriately and efficiently allocate organizational resources will have a strong impact on a business. As mentioned in the Resource-based View theory, Barney (1991) further argues that to have the potential to generate competitive advantage, a firm's resource must have four attributes: valuable, rare, inimitable, and non-substitutable. Bozeman and Straussman (1990) offer three types of organizational resources, consist of personnel resources, financial resources and organizational structure. Physical resources such as the plant, machinery, equipment, production technology and capacity have contributed positively towards organizational competitive advantage and eventually result in superior firm's performance (Morgan et al., 2004). Grant (1991) suggested the following categories as organizational resources, which include financial resources, physical resources, human resources, technological resources, reputation, and organizational resources. Physical resources such as the plant, machinery, equipment, production technology and capacity have contributed positively towards organizational competitive advantage and eventually result in superior firm's performance (Morgan et al., 2004; Ainuddin et al., 2007).

\subsection{Rewards and Recognition Structure}

As organizations look for key differentiators that can create competitive advantages and a stronger bottom line, they inevitably arrive at people issues as a key source of untapped potential. Rewards and recognition are remuneration based system, which include bonus, perks, allowances, awards, and certificates used as a highly effective means of motivating and engaging employees (Monis, 2011). Wright et al. (1993) have shown that the human resources can be a source of competitive advantage because they meet the criteria for being a source of sustainable competitive advantage. Human resources add value to the firm, are rare, cannot be imitated and are not sustainable. Ali and Ahmed (2009) argue that human assets are a key source of sustainable advantage because of causal ambiguity and systematic information making them inimitable. This means success does not depend primarily on the size of the budget or the products supporting technologies. It really depends on employee's attitudes, competencies and skills, their ability to generate commitment and trust, communicate aspirations and work in complex relationships.

Pfeffer (1994) has issued sixteen practices of competitive advantage through people. There are: employment security, incentive pay, participation and empowerment, symbolic egalitarianism, long-term perspective, selectivity in recruiting, employee ownership, teams and job redesign, wage compression, measurement of practices, cross-utilization and cross-training, high wage, information sharing, training and skill development, promotion from within, and, overarching philosophy. To ensure that people are treated fairly, organisations are acknowledging that they need to establish an equitable balance between employee contribution to the organisation and the organisation's contribution to the employee. According to Deeprose (1994), establishing this balance and meeting this need is one of the first reasons to reward and recognise employees. Monis (2011) suggests that rewards and recognition, both financial and otherwise, is a powerful approach to create and maintain, and what kind of behaviour and attitudes management seeks from its employees. According to Lawler (2003), there are at least two factors that determine the attractiveness of a reward; one is how much of the 
reward is being offered and the second is how much the individual values the type of reward that is being offered. He argues that the more the individual values the type of reward and the more of it is being offered, the greater the motivational potential.

Therefore the reward issue cannot be ignored, as it will create a situation in which the expectation or the actual goal-directed behaviour of one person or group are blocked or are about to be blocked (Danish \& Usman, 2010). Hofer (2005) suggests that this sort of issues management must address and design fair reward systems that can satisfy the employee because the employee's satisfaction can be translated into customer satisfaction which can be translated into profit. Promoting and sustaining a good and harmonious working environment will make employees feeling appreciated and being recognized by their employers (Caudroit et al., 2011). Employees expect more control over their work experience, careers and financial status. Employers are also looking for more in terms of productivity, flexibility and commitment. Lawler (2003) supports this in stating that people need both motivation and ability. Lawler says that highly motivated workers will not achieve results if they do not have the necessary skills, expertise and attitude that the organisation requires of them. He furthers says that employees with expertise, knowledge and skills will not do well if they are unmotivated. Baron (1983) posits the view that if successful performance does in fact lead to organisational rewards, such performance could be a motivational factor for employees. The reward and recognition structure can therefore be seen as a set of relationships between the various reward management processes and the corporate strategy.

\subsection{Information System}

One of the hot research topics currently is research about strategic information system. Its aspects and project management information system have changed considerably over the last decade (Ahlemann, 2009). The potential usefulness of different kinds of information system for environmental management is well recognized (Díez \& McIntosh, 2009). Advances in information provision have led organizations to attempt to develop information system strategies which interrelate with their business strategies and which together support corporate missions (Rogerson \& Fidler, 1994).

Applying resource-based in context of information systems are potential in order to identification of key motivations for enhanced firm performance (Jeffers et al., 2008). Ray et al. (2005) supports the view of Jeffers et al. (2008) that the Resource-based View theory which describes that information technology resources and capability lead to efficiency on the performance of the customer service. Ray et al. (2005) add that the effects of information technology are best documents at the level of firm and they are unique on firm performance. In addition, Doherty and Terry (2009) say that resource-based view support effect of using information system capabilities for constant competitive advantage delivery. In their research findings, Doherty and Terry (2009) claim that investment in set of information system capabilities in long-term will succeed inside of firm and competitive environment.

In the information systems area, many studies have examined the relationship between information system, competitive advantage and firm performance. According to Porter (1985), information system has a dominant effect on competitive advantages in either cost or differentiation. The technology also affects value activity themselves or allows companies to gain competitive advantage by utilizing changes in competitive scope. Porter (1985) state that the information system is affecting competition in three fundamental ways: (1) it changes industry structure and, in so doing, alters the rules of competition, (2) it creates competitive advantage by giving companies new way to outperform their rivals, and (3) it spawns a whole new business, often from within a company's existing operations.

\subsection{Quality of Production}

The past few years have seen considerable evidence presented on the importance of product and service quality to corporate survival in the marketplace (Singh \& Soltani, 2010). Most modern companies recognize the need to alter their thinking in terms of quality and how that can improve their business performance. Quality Management has become an essential strategy in both manufacturing and service organizations. Quality has been identified as one of the competitive strategies for improving the business performance in a global market (Gurnani, 1999). Many firms are pursuing quality management implementation to deliver high-quality products and services and hence to achieve their business objectives (Gunasekaran, 1999).

From the perspective of manufacturing, quality means conformance to specifications. Specifications are targets and tolerances by designers of products. Targets are the ideal values for which production is expected to strive, while tolerances are the acceptable deviations from these ideal values. There will always be variations in the production process. While variations cannot totally be eliminated in the production of products, organizations can strive to minimize around target values. This minimizes the economic loss and benefits both the producer 
and the consumer. Quality production include product design, purchasing, production planning and scheduling, engineering and maintenance of tools and equipments, packaging, shipping, warehousing, and ancillary functions to support the quality efforts, such as human resources, finance, and legal services (Alwan, 2012). Given the importance of organizational factors that have been discussed, this study suggested the following hypotheses.

H1: There is a positive relationship between organizational resources and quality of production in Malaysia's manufacturing companies.

H2: There is a positive relationship between rewards and recognition structure and quality of production in Malaysia's manufacturing companies.

H3: There is a positive relationship between information system and quality of production in Malaysia's manufacturing companies.

\section{Methodology of Research}

This study used a seven-point Likert scale questionnaire as the research instrument. Questionnaires were distributed to 600 companies that were registered under the Federation of Malaysian Manufacturers at the surrounding areas of the territory of Selangor, Penang, Kedah, Johore, Sabah, Sarawak, and the Federal Territory of Kuala Lumpur and Labuan. Due to the nature of the unit of analysis which was heterogeneous, disproportionate stratified random sampling was applied. 233 out of the 600 distributed questionnaires were returned and only 201 were usable for further analysis. The target group of the study composed of the presidents of the company, executive directors, general managers, accountants or financial controllers, and managers in multi-disciplined (such as, human resource, factory, marketing, sales, administration and etc.). Of the 201 firms in the 16 different industries surveyed, 33 firms were in the electrical and electronics industry, 28 in the chemical and petroleum industry, 27 in the food, beverage and tobacco products, 22 in the fabricated metal, 11 each in the basic metal industry, and paper, printing and publishing, 9 each in transport and plastic products, 17 in the wood products (including furniture), 14 in the non-metallic mineral products, 7 each in the rubber industry, and textile, wearing apparel and leather products, 3 in the medical, precision and optical instruments, 2 in machinery and 1 in other industry.

As aforesaid, the purpose of this research is to investigate the relationship between organizational factors and quality of production in Malaysia's manufacturing companies. In order to do that, this research has to elucidate the types of organizational factors associated with quality of production. Although the research on organizational factors cannot be all inclusive, it provides information that may be useful to enhance the performance of an organization. The organizational factors construct in this study is a multidimensional construct. This construct was represented by eleventh items; i.e., organizational resources (4 items), information system (4 items), and rewards and recognition structure (3 items). A principle component method with a varimax rotation was utilized in order to reduce a large number of variables to a smaller numbers of factors. Before conducting an exploratory factor analysis, the researcher performed two tests to check the possible presence of multicollinearity or correlation among items and the appropriateness of factor analysis. A principle component method with a varimax rotation was utilized in order to reduce a large number of variables to a smaller numbers of factors. The final run of factor analysis in this study produced three factors with only 10 items were developed with eigenvalues more than one which explained 79.46 of the total variance. The Kaiser-Meyer-Oklin value was 0.77 and the Bartlett test of sphericity was significant at 0.00 . Anti-image correlation of the remaining 10 items of organizational factors exceeded 0.5. The communalities of the 10 items ranged from 0.51 to 0.90 . The factor loadings for the remaining 10 organizational factors variables were in the range of 0.49 to 0.94 , which indicates above recommended cut-off point value of 0.40 for practical and statistical significance. Overall, all the variables were loaded significantly on three factors as conceptualized; therefore the same label was used to label these factors. 'Organizational resources' consists of five variables with eigenvalue of 5.17 which accounted of $23.76 \%$ of the total variance. Factor two was labelled as "rewards and recognition structure" since the items portrayed the organization effort to rewards and recognize its employees. The three items measured approximately $18.77 \%$ of the variance was captured by factor two that has an eigenvalue of 2.07 . Factor three was labelled as "information system" which has two items measured with eigenvalue of 1.70 which explained $13.80 \%$ of the total variance.

For 'quality of production', the initial run of the factor analysis on 5 items produced an eigenvalues above one. The Kaiser-Meyer-Oklin value was 0.86 and the Bartlett test of sphericity was significant at 0.00 . Anti-image correlation for the entire variables were greater than 0.5 . After the final run of factor analysis on quality of production, only 3 items were retained. The factor loadings for the remaining 3 were in the range of 0.85 to 0.87 , 
which indicated above recommended cut-off point value of 0.40 for practical and statistical significance. It has eigenvalue of 6.36 which accounted of $28.95 \%$ of the total variance.

Cronbach's alpha was performed all of the variables of this study and the results are as presented in Table 1. All of the cronbach's alpha values disclosed significantly over 0.80 . The reliability coefficient of 0.70 or higher is considered acceptable in most social science research situations.

Table 1 . Table reliability analysis on variables $(n=201)$

\begin{tabular}{llll}
\hline Construct & Variables/Dimension & No. of Items & Cronbach's alpha \\
\hline Organizational Factors & Organizational Resources & 5 & 0.88 \\
& Rewards and Recognition Structure & 3 & 0.89 \\
& Information System & 2 & 0.87 \\
\hline
\end{tabular}

Table 2 presents the scores of all the variables applied in this study, along with all means and standard deviations. The results show that the mean scores for each of the three dimensions varied from 4.99 to 5.78 , indicating that respondents had a moderate opinion of all the dimensions. The standard deviation for these components ranged from 0.65 to 1.14 .

Table 2. Mean and standard deviation of measures $(n=201)$

\begin{tabular}{llll}
\hline & Construct/Dimension & Mean & Std. Deviation \\
\hline Organizational Factors & Organizational Resources & 5.78 & 0.65 \\
& Reward \& Recognition Structure & 5.47 & 0.77 \\
& Information System & 4.99 & 1.14 \\
\hline
\end{tabular}

The results indicated that all of the organizational factors dimensions were positively correlated with quality of production. All of the organizational factors dimensions were found to have either a moderate or weak correlation. The association of organizational resources had a moderate correlation with quality of production ( $\mathrm{r}$ $=0.41, \mathrm{p}<0.01)$. The same goes to rewards and recognition structure which had a weak correlation with quality of production $(\mathrm{r}=0.25, \mathrm{p}<0.01)$. Information system however had a moderate correlation with quality of production $(\mathrm{r}=0.40, \mathrm{p}<0.01)$.

Table 3. Correlation matrix amongst constructs $(\mathrm{n}=201)$

\begin{tabular}{|c|c|c|c|c|c|}
\hline Variables & $\begin{array}{l}\text { Organizational } \\
\text { Resources }\end{array}$ & $\begin{array}{l}\text { Reward } \\
\text { Recognition }\end{array}$ & $\&$ & Information System & Quality of Production \\
\hline Organizational Resources & 1 & & & & \\
\hline Reward \& Recognition & $0.418^{* *}$ & 1 & & & \\
\hline Information System & $0.450 * *$ & $0.285^{* *}$ & & 1 & \\
\hline Quality of Production & $0.413 * *$ & $0.250 * *$ & & $0.395^{* *}$ & 1 \\
\hline
\end{tabular}

The results in Table 3 revealed that $24.4 \%$ of the total variances in quality of production were explained by organizational resources, rewards and recognition structure, and information system $\left(R^{2}=24.4, p<0.01\right)$. The results indicated that two of the organizational factors dimensions were found to have significant influences on quality of production, i.e., organizational resources $(\beta=0.231, \mathrm{p}<0.01)$ and information system $(\beta=0.221, \mathrm{p}<$ 0.01). Hence, two hypotheses, i.e., H1 and H3 were supported. Surprisingly, one of the variables does not show correlation with the quality of production in Malaysia's manufacturing firms. The only remaining dimension i.e. rewards and recognition structure (i.e., H2) was not supported ( $\mathrm{p}>0.01)$. 
Table 3. Multiple regression analysis of organizational factors with quality of production

\begin{tabular}{llll}
\hline Dependent Variable & Independent Variable & Std. Coefficient Beta $(\beta)$ & Sig. \\
\hline Quality of Production & Organizational Factors: & & 0.003 \\
& Organizational Resources & $0.231^{* *}$ & 0.314 \\
& Rewards and Recognition Structure & 0.070 & 0.002 \\
\hline & Information System & $0.221^{* *}$ & \\
\hline $\mathrm{R}^{2}$ & 0.244 & 0.229 \\
& Adjust $\mathrm{R}^{2}$ & $15.83^{* *}$ & \\
\hline
\end{tabular}

Note. Significant levels: $* * \mathrm{p}<0.01, * \mathrm{p}<0.05$.

\section{Discussion, Implications and Conclusion}

This research hypothesized positive relationship between organizational factors and quality of production in Malaysia's manufacturing industry, except for one which is related to rewards and recognition structure. The first dimension of organizational factors in this research is organizational resources. There was a positive association between organizational resources and quality of production which stood alongside with previous studies, which the relationship between organizational resources and quality of production existed in a positive way. This was consistent to previous empirical studies that organizational resources played an important role in manufacturing companies for increased competitiveness and profitability (e.g., Ndofor et al., 2011).

When the regression analysis process was conducted, it was found that rewards and recognition structure had insignificant relationship with quality of production, which indicates that employees would not always be motivated neither by rewards nor by recognition alone. This finding is inconsistent with Feldman (1996) and Monis (2011) that high-performance companies offer awards and incentives that recognize, validate and value outstanding work, as to keep employees motivated. There might be many possible reasons why there is significant correlation between these two variables in the manufacturing companies in Malaysia. Even though Monis (2011) suggested that rewards and recognition were equally important when trying to promote performance and morale amongst employees, the result showed that employees would not always be motivated neither by rewards nor by recognition alone in Malaysia, particularly in manufacturing sector. The award must be based not only on their performance but also product's performance as recommended by Feldman (1996) and Kunkel (1997). Both cited researchers recommended that evaluation factors like meeting time targets or meeting and exceeding revenue and profit goals, and achieving customer satisfaction can be used to determine the size of an award. Hence, managers should consider carrying out an effective performance reward and recognition system for employees' performance and job well done.

Up-to-date, complete and accurate information system had become a necessity for survival in a competitive world and was implemented for the purpose of improving the effectiveness and efficiency of the organization (Roberts \& Grover, 2012). Information system plays a very important role in the organization as it creates an impact on the organization's function, performance and productivity. In this study, the findings show that information system has a high association with quality of production and the results of this study consistent with the result of the previous studies (i.e., Yuan et al., 2005; Mithas \& Narayan, 2011; Lu \& Ramamurthy, 2011; Litwin, 2011; Roberts \& Grover, 2012). It is suggested that managers need to create and use information systems successfully to gain advantage over competitors as also suggested by Wiseman and MacMillan (1984). The result demonstrated that manufacturing companies in Malaysia perceive information system played an important role in their daily operations. It was proven that information systems were predominantly developed in-house in manufacturing companies in Malaysia. According to Azlinah and Syed Abu Bakar (2004), Malaysian government had contributed a lot through the Multimedia Super Corridor as the major information system development project that was capable to justify the future of information system in Malaysia.

The results of this study provide important implications for management and organizational leaders. The research finding shows that there is a significant correlation between organizational resources and level of quality of production performed by organization. This implies that one of the keys to higher performance is the organization's resources. It is suggested that managers should plan and allocate resources effectively and efficiently such as assets, organizational core competencies, knowledge, and processes to attain organizational specific goal. This consists of effective policies for handling raw materials, machines and equipment during the manufacturing process, which lead to low handling cost, reduce manufacturing cycle time, better control of goods flow, less rejects, and decrease storage requirements (Nahavandi, 2009; Akkerman et al., 2010; Safaei et 
al., 2010; Han et al., 2012). Good materials, machines and equipment handling systems give the organization control on productivity (Sople, 2007). In addition, one of the most important aspects of manufacturing processes, particularly in inventory management is to have the materials in stock at the moment they are needed. This includes going into the market to purchase the goods early enough to ensure delivery at the proper time ( $\mathrm{Li} \&$ Ryan, 2012; Goeke \& Faley, 2009).

Apart from the aforementioned recommendations above, the study also suggests that managers should consider improving their procurement process that works with the suppliers and analyze the process to understand where opportunities exist to eliminate waste and increase value delivery. Likewise, employees' skills and knowledge of the company's work systems are an essential element of an effective manufacturing process. There should be the right combination of people, technology and structure that makes full use of the organization's resources and opportunities in achieving its goals (Fabiyola et al., 2010). Managers should also consider paying attention to development of efficient work practice as skills and knowledge and a high performance work system should be blended together. As a conclusion, organizational factors in this research exert a powerful influence on the ability to producing high quality products. Each of the aforementioned dimensions (except for rewards and recognition structure) plays an important role in shaping the quality culture of manufacturing companies in Malaysia.

\section{References}

Ahlemann, F. (2009). Towards a Conceptual Reference Model for Project Management Information Systems. $\begin{array}{llll}\text { International Journal of Project } & \text { Management, }\end{array}$ http://dx.doi.org/10.1016/j.ijproman.2008.01.008

Ainuddin, R. A., Beamish, P. W., Hulland, J. S., \& Rouse, M. J. (2007). Resource Attributes and Firm Performance in International Joint Ventures. Journal of World Business, 42, 47-60. http://dx.doi.org/10.1016/j.jwb.2006.11.001

Akkerman, R., Van Der Meer, D., \& Van Donk, D. P. (2010). Make to Stock and Mix to Order: Choosing Intermediate Products in the Food-Processing Industry. International Journal of Production Research, 48(12), 3475-3492. http://dx.doi.org/10.1080/00207540902810569

Ali, R., \& Ahmed, M. S. (2009). The Impact of Reward and Recognition Programs on Employee's Motivation and Satisfaction: An Empirical Study. International Review of Business Research Papers, 5(4), 270-279.

Alwan, B. M. (2012). Effectiveness of TQM and its Impact on Production Costs to Make a Profit in Industrial Companies. Interdisciplinary Journal of Contemporary Research in Business, 3(11), 753-766.

Azlinah, M., Syed A., \& Bakar, S. H. (2004). Evolution of Information Systems in Malaysia. Electric Government Third International Conference, Zaragoza, Spain, Lecture Notes in Computer Science 3183.

Barney, J. (1991). Firm Resources and Sustainable Competitive Advantage. Journal of Management, 17(1), 99-120. http://dx.doi.org/10.1177/014920639101700108

Barney, J. B. (1986). Strategic Factor Markets: Expectations, Luck, and Business Strategy. Management Science, 32(10), 1231-1242. http://dx.doi.org/10.1287/mnsc.32.10.1231

Baron, R. A. (1983). Behaviour in Organisations. New York: Allyn \& Bacon, Inc.

Bozeman, B., \& Straussman, J. D. (1990). Public Management Strategies: Guidelines for Managerial Effectiveness. San Francisco, CA: Jossey-Bass.

Caudroit, J., Boiche, J., Stephan, Y., Le Scanff, C., \& Trouilloud, D. (2011). Predictors of Work/Family interference and Leisure-Time Physical Activity among Teachers: The Role of Passion towards Work. European Journal of Work \& Organizational Psychology, 20(3), 326-344. http://dx.doi.org/10.1080/13594320903507124

Chaplin, W. F. (1991). The Next Generation in Moderation Research in Personality Psychology. Journal of Personality, 59, 143-178. http://dx.doi.org/10.1111/j.1467-6494.1991.tb00772.x

Danish, R. Q., \& Usman, A. (2010). Impact of Reward and Recognition on Job Satisfaction and Motivation: An Empirical Study from Pakistan. International Journal of Business \& Management, 5(2), 159-167.

Deeprose, D. (1994). How to Recognise and Reward Employees. New York: AMACOM.

Diez, E., \& McIntosh, B. S. (2009). A Review of the Factors which Influence the Use and Usefulness of Information Systems. Environmental Modelling \& Software, 24(5), 588-602. http://dx.doi.org/10.1016/j.envsoft.2008.10.009 
Doherty, N., \& Terry, M. (2009). The Role of IS Capabilities in Delivering Sustainable Improvements to Competitive Positioning. Journal of Strategic Information Systems, 18, 100-116. http://dx.doi.org/10.1016/j.jsis.2009.05.002

Fabiyola, K. S., Manicka, V. S. P., \& Murugadoss, S. (2010). An Empirical Study on Employee Core Competencies a Proven Tool for an Organization's Success. Interdisciplinary Journal of Contemporary Research in Business, 2(8), 120-132. http://dx.doi.org/10.1108/03090560410539140

Fahy, J., Farrelly, F., \& Quester, P. (2004). Competitive Advantage through Sponsorship: A Conceptual Model and Research Propositions. European Journal of Marketing, 38(8), 1013-1030.

Feldman, L. P. (1996). The Role of Salary and Incentives in the New Product Function. Journal of Product Innovation Management, 1, 216-228. http://dx.doi.org/10.1111/j.1540-5885.1996.jpim133_0216.xml.x

Goeke, R. J., \& Faley, R. H. (2009). Do SAP Successes Outperform Themselves and Their Competitors? Communications of the ACM, 52(10), 113-117. http://dx.doi.org/10.1145/1562764.1562793

Grant, R. M. (1991). The Resource-Based Theory of Competitive advantage: Implications for Strategy Formulation. California Management Review, 30(3), 114-136. http://dx.doi.org/10.2307/41166664

Gunasekaran, A. (1999). Enablers of Total Quality Management Implementation in Manufacturing: A Case Study. Total Quality Management, 10(7), 987-996. http://dx.doi.org/10.1080/0954412997172

Gurnani, H. (1999). Pitfalls in Total Quality Management Implementation: The Case of a Hong Kong Company. Total Quality Management, 10(2), 209-228. http://dx.doi.org/10.1080/0954412997965

Hajihashemi, M., \& Javadi, M. H. M. (2011). Identification and Prioritizing Effective Factors on Organizational Creativity Based on MADM techniques (Case study: Saadi Hospital in City of Isfahan). Interdisciplinary Journal of Contemporary Research in Business, 3(5), 239-248.

Han, G., Dong, M., \& Shao, X. (2012). Yield Management with Downward Substitution and Uncertainty Demand in Semiconductor Manufacturing. International Journal of Production Research, 50(3), 743-756.

Hofer, C. (2005). Whole of Life Focus. Management, 18(3), 10-14. http://dx.doi.org/10.1080/00207543.2010.543942

Jeffers, I., Muhanna, W., \& Nault, B. (2008). Information Technology and Process Performance: An Empirical Investigation of the Interaction between IT and Non-IT Resources. Journal Compilation, Decision Sciences Institute, 31(4), 1-33.

Khakbaz, P. P., Kazemi, R. M., \& Zarei, B. (2011). Identifying Effective Organizational Factors on Corporate Entrepreneurship in Tehran Municipality's Department of Urban Services. Information Management and Business Review, 3(6), 328-335.

Kunkel, J. G. (1997). Rewarding Product Development Success. Research Technology Development, 40(5), 29-31.

Lawler, E. E. (2003). Treat People Right. San Francisco: Jossey-Bass Inc.

Li, R., \& Ryan, J. K. (2012). Inventory Flexibility through Adjustment Contracts. International Journal of Production Research, 50(7), 1955-1978. http://dx.doi.org/10.1080/00207543.2011.564667

Litwin, A. S. (2011). Technological Change at Work: The Impact of Employee Involvement on the Effectiveness of Health Information Technology. Industrial and Labor Relations Review, 64(5), 863-888.

Lu, Y., \& Ramamurthy, K. (2011). Understanding the Link between Information Technology Capability and Organizational Agility: An Empirical Examination. MIS Quarterly, 35(4), 931-954.

Mithas, S. R., \& Narayan, S. V. (2011). How Information Management Capability Influences Firm Performance. MIS Quarterly, 35(1), 137-172.

Monis, H. (2011). Employee Perceptions of Reward and Recognition Policy of Indian MNC BPO Firms: An Empirical Study. International Journal of Business Economics \& Management Research, 2(7), 19-28.

Mora-Valentin, E. M., Montoro-Sanchez, A., \& Guerras-Martin, L. A. (2004). Determining Factors in the Success of R\&D Cooperative Agreements between Firms and Research Organizations. Research Policy, 33(1), 17-40. http://dx.doi.org/10.1016/S0048-7333(03)00087-8

Morgan, N. A., Kaleka, A., \& Katsikeas, C. S. (2004). Antecedents of Export Venture Performance: A Theoretical Model and Empirical Assessment. Journal of Marketing, 68, 90-108. 
http://dx.doi.org/10.1509/jmkg.68.1.90.24028

Nahavandi, N. (2009). CWIPL II, a Mechanism for Improving throughout and Lead time in Unbalanced Flow Line. International Journal of Production Research, 47(11), 2921-2941. http://dx.doi.org/10.1080/00207540701725059

Naji, M., Taboli, H., \& Zolfaghari, A. (2012). Relationships between Organizational Factors and Political Behaviour Tactics in the Islamic Republic of Iran: Kerman Province. International Journal of Economics and Finance, 4(6), 108-115. http://dx.doi.org/10.5539/ijef.v4n6p108

Ndofor, H. A., Sirmon, D. G. \& He, X. (2011). Firm Resources, Competitive Actions and Performance: Investigating a Mediated Model with Evidence from the In-Vitro Diagnostics Industry. Strategic Management Journal, 32(6), 640-657. http://dx.doi.org/10.1002/smj.901

Pfeffer, J. (1994). Competitive Advantage through People. Harvard: HBS Press.

Porter, M. E. (1985). Competitive Advantage. New York: Free Press.

Ray, G., Muhanna, W., \& Barney, J. (2005). Information, Technology and the Performance of the Customer Service Process: A Resource-Based Analysis. MIS Quarterly, 29(4), 625-651.

Roberts, N., \& Grover, V. (2012). Leveraging Information Technology Infrastructure to Facilitate a Firm's Customer Agility and Competitive Activity: An Empirical Investigation. Journal of Management Information Systems, 28(4), 231-270. http://dx.doi.org/10.2753/MIS0742-1222280409

Rogerson, S., \& Fidler, C. (1994). Strategic Information Systems Planning: Its Adoption and Use. Information Management and Computer Security Journal, 20(4), 12-17. http://dx.doi.org/10.1108/09685229410058740

Safaei, N., Banjevic, D., \& Jardine, A. K. S. (2010). Impact of the Use-based Maintenance Policy on the Performance of Cellular Manufacturing Systems. International Journal of Production Research, 48(8), 2233-2260. http://dx.doi.org/10.1080/00207540802710273

Seddon, P. B., Calvert, C., \& Yang, S. (2010). A Multi-Project Model of Key Factors Affecting Organizational Benefits from Enterprise Systems. MIS Quarterly, 34(2), 305-328.

Singh, A., \& Soltani, E. (2010). Knowledge management practices in Indian information technology companies. Total Quality Management \& Business Excellence, 21(2), 145-157. http://dx.doi.org/10.1080/14783360903549832

Sople, V. V. (2007). Material Handling Equipment: Exploiting Productivity Potential in Supply Chain. Search, $10(10), 1-7$.

Wiseman, C., \& MacMillan, I. C. (1984). Creating Competitive Weapons from Information Systems. The Journal of Business Strategy, 5(2), 42-49. http://dx.doi.org/10.1108/eb039057

Wright, P. M., McMahan, G. C., \& McWilliams, A. (1993). Human Resources and Sustained Competitive Advantage: A Resource-Based Perspective (pp. 1-34). Center for Effective Organizations.

Yuan, Y., Fulk, J., Shumate, M., Monge, P., Bryant, J., \& Matsaganis, M. (2005). Individual Participation in Organizational Information Commons. Human Communication Research, 31(2), 212-240.

\section{Copyrights}

Copyright for this article is retained by the author(s), with first publication rights granted to the journal.

This is an open-access article distributed under the terms and conditions of the Creative Commons Attribution license (http://creativecommons.org/licenses/by/3.0/). 